\title{
ARTIKELEN
}

\author{
THEMA-ARTIKEL
}

\section{Bestuurlijke manie bij prestigeprojecten: van maquette naar mislukking*}

\author{
Wouter Jan Verheul \& Meike Bokhorst
}

\begin{abstract}
Prestigeprojecten bieden veel inzicht in de werking van het openbaar bestuur. Vooral prestigieuze stadsprojecten kunnen ons veel leren over wat we willen noemen: 'bestuurlijke manie'. We signaleren bij dit soort projecten namelijk typische eigenschappen van bestuurlijke manie, te weten extreme uitgelatenheid, overdreven positief zelfbeeld, aanstekelijk enthousiasme, selectieve argumentatie, tunnelvisies en ongefundeerd vertrouwen in een goede afloop. Als gevolg van bestuurlijke manie lopen prestigieuze projecten het risico om uit de hand te lopen qua kosten en ook niet datgene op te leveren wat ervan wordt verwacht en beloofd. In dit artikel willen we het verschijnsel 'bestuurlijke manie' uitdiepen door onder andere de symptomen ervan te benoemen, de implicaties ervan aan te geven, de manische mechanismen te analyseren en ten slotte te bekijken hoe men zich tegen bestuurlijke manie kan wapenen.
\end{abstract}

Zolang steden bestaan, wordt er gewerkt aan prestigeprojecten. Sommige daarvan lopen uit op een fiasco. Van de toren van Babel tot aan een leeg stadion voor een WK voetbal of Olympische Spelen. Van een ingestorte brug met een gebrekkige uitvoering, tot aan de nieuwbouw van een stadhuis waarbij de kosten uit de hand lopen en het stadsbestuur valt. Prestigeprojecten hebben naast hun primaire gebruiksfunctie ook hun raison d'être in het op de kaart zetten van de stad, het aantrekken van nieuwe bewoners en bezoekers, en het versterken van trots onder de lokale bevolking (Ashworth, 2010; Hospers, Verheul \& Boekema, 2011). Op zichzelf zijn dit legitieme gronden ter bevordering van prestigieuze stadsprojecten, maar deze projecten kunnen mislukken, omdat ze niet van de grond komen, of omdat ze worden gerealiseerd tegen veel te hoge kosten en te weinig opbrengsten. We kennen het allemaal: een foto in de krant van een trotse wethouder of burgemeester die verlekkerd naar een maquette staat te kijken (Sudjic, 2005).

* $\quad$ Dr. W.J. Verheul is als universitair docent en onderzoeker verbonden aan de afdeling Urban Development Management van de Technische Universiteit Delft en is daarnaast zelfstandig adviseur te Rotterdam. Dr. A.M. Bokhorst is senior onderzoeker bij de Wetenschappelijke Raad voor het Regeringsbeleid (WRR) en is tevens verbonden aan de Universiteit Utrecht. De auteurs bedanken prof. dr. Alfons van Marrewijk (VU Amsterdam/TU Delft), prof. dr. Nico Nelissen (Radboud Universiteit Nijmegen) en prof. dr. Lars Tummers (Universiteit Utrecht) voor hun lezing, feedback en/of literatuursuggesties. 
Prestigeprojecten zijn niet alleen bedoeld voor het prestige van de stad waarin ze worden ontwikkeld, maar dienen soms (indirect) ook als persoonlijke 'legacy building': als een een monument voor bestuurders. We gebruiken in dit artikel het woord bestuurder breed, dus voor zowel (uitvoerende) politici als voor de ambtelijke top.

Prestigeprojecten hebben een functie voor de samenleving en voor het openbaar bestuur. Ze versterken de lokale cultuur en identiteit (Verheul, 2012). De nieuwbouw van een stadhuis bijvoorbeeld kan niet alleen zo sober mogelijk worden uitgevoerd, maar ook met een opvallende (prestigieuze) architectuur. Burgers hekelen verspilling van belastinggeld, maar vinden tegelijkertijd dat een stadhuis ook voldoende statuur moet hebben als we er trouwen, delegaties uit binnen- en buitenland ontvangen, of sportclubs huldigen. Een rechtbank - ook wel 'paleis van justitie' genoemd - verdient een architectuur die het gezag van de rechtsstaat onderstreept, en dat lukt minder goed met een goedkoop ogende uitvoering (Klop, 1999). Ook zorg- en onderwijsgebouwen moeten uitstralen dat ze - letterlijk en figuurlijk - maatschappelijke waarden vertegenwoordigen die we als welvarende samenleving hoog in het vaandel hebben staan.

Prestigieuze stadsprojecten komen niet vanzelf tot stand, ze vragen om vergezichten, om bestuurders met lef, om initiatiefnemers met grootse dromen. Rondom zulke projecten vindt vrijwel altijd strijd plaats over de locatie, het ontwerp en de kosten (Nelissen, 2003). Daarom heeft het openbaar bestuur een grote overtuigingskracht nodig om de omgeving mee te krijgen en het geloof te versterken in de waarde van het project voor de stad (Verheul, 2012). Maar daardoor kunnen we door zulke projecten wel betoverd, of zelfs verblind raken. Het openbaar bestuur raakt er niet zelden in verstrikt: er is sprake van een tunnelvisie, waardoor een evenwichtig zicht op de kosten en opbrengsten verloren gaat (Flybjerg, 2014).

\section{Een gedragsbestuurskundige blik}

De prestigeprojecten die op een fiasco uitlopen, spelen zich vaak af binnen de context van bestuurlijke manie. Net als de manische persoon spelen daarbij eigenschappen een rol zoals uitgelatenheid, extreem positivisme, groot zelfvertrouwen en aanstekelijk enthousiasme, afgewisseld met tunnelvisies, besluiteloosheid, roekeloosheid en (zelf)destructief gedrag.

Hoewel wij hier vooral ingaan op fysieke (stads)projecten, komt bestuurlijke manie ook op andere beleidsterreinen voor. Het verschijnsel 'manie' bij bestuurlijk gedrag zien we vaak bij grote, controversiële projecten. Prestigeprojecten vertegenwoordigen twee kanten van één en dezelfde medaille: opleving en betovering enerzijds, mislukking en teleurstelling anderzijds. Wie de ontwikkeling van grote stadsprojecten volgt, ziet dat beide zijden van de medaille zich afwisselend of gelijktijdig voordoen. Willen we het verschijnsel 'bestuurlijke manie' beter begrijpen, dan zijn theoretische en empirische inzichten in de oorzaken, de symp- 
tomen, de mechanismen en de gevolgen ervan noodzakelijk. Dit vraagt om een (sociaal-)psychologische kijk op bestuur en management van projecten. Een analytisch perspectief dat aansluit bij de zogenoemde gedragsbestuurskunde die de laatste jaren furore maakt (Tummers, Olsen, Jilke \& Grimmelikhuijsen, 2016).

De opbouw van dit artikel is als volgt. We beschrijven allereerst prestigeprojecten waarbij we zowel ingaan op de bestuurlijke manie als de implicaties ervan voor die projecten. We geven voorbeelden van prestigeprojecten die uit de hand zijn gelopen qua kosten en waarvan de opbrengsten tegenvallen. Vervolgens analyseren we het fenomeen bestuurlijke manie nader en presenteren een overzicht van hiervoor karakteristieke symptomen en gedragsmechanismen. We sluiten dit artikel af met wat de bestuurskundige waarde is van studie naar bestuurlijke manie, en bekijken of en hoe men zich tegen manie kan wapenen.

\section{Prestigeprojecten nader verkend}

Wat is het eigene van prestigeprojecten? En waarom voelen bestuurders zich ertoe aangetrokken? Bij het definiëren van prestigeprojecten zijn de vier 'sublimes' behulpzaam die Flyvbjerg (2014) heeft beschreven. Traditoneel is er bij prestigieuze of grote projecten de vervoering van een 'technical sublime', denk daarbij aan de hoogste toren, het grootste stadion, of 'het eerste van iets bijzonders'. Daarnaast is er de 'political sublime': bestuurders die prestigeprojecten als een eerbetoon aan zichzelf laten bouwen; het liefst met projecten die nadrukkelijk zichtbaar zijn in het stedelijk landschap en werken als een magneet voor publieke en media-aandacht, zoals bij de presentatie van een projectinitiatief met een maquette, of bij het doorknippen van het lint tijdens de opening. Ook zien we een 'economic sublime': grote, prestigieuze projecten vragen om enorme budgetten, maar creëren tegelijkertijd een economische impuls voor opdrachtnemers, architecten, ingenieurs, ontwikkelaars, bankiers, investeerders, advocaten, consultants en bouwvakkers. Ten slotte is er de 'aesthetic sublime', wat het plezier aangeeft dat ontwerpers en liefhebbers van goed design kunnen ontlenen aan sommige prestigeprojecten. Al deze 'sublimes' zijn belangrijke drijvende krachten achter de vereenzelviging van bestuurders met prestigeprojecten. Dit geldt niet alleen voor de bestuurders, maar ook voor de steunverleners die er voordeel mee behalen.

Prestigeprojecten zijn vaak kostbaar, maar kunnen ook veel opleveren. Zo waren de oorspronkelijke kosten voor het Sydney Opera House geraamd op \$ 7 miljoen met als opleverdatum 26 januari 1963. Maar het project kostte uiteindelijk \$ 102 miljoen en werd pas in 1973 geopend. Dit project werd na realisatie aanvankelijk gezien als een groot fiasco, maar op lange termijn bleek het een investering te zijn waarmee Sydney op de kaart werd gezet (Hall, 1980). Een ander voorbeeld van een goede return on investment is het Guggenheim Museum in Bilbao, een stad die voorheen de vuilnisbeltstad van Spanje werd genoemd, maar dat sinds de komst van het markante museum veel positieve spin-offs kent, zoals de bestedingen door bezoekers en de enorme stimulans voor de toeristische en creatieve sector (Plaza, Galvez-Galvez \& Gonzalez-Flores, 2011). 
Prestigeprojecten zijn vaak iconen van een stad, die zich onderscheiden door hun symbolische betekenis (Verheul, 2012). Die symbolische functie is volgens Van Marrewijk (2017) 'multivocaal'; daarmee wordt bedoeld dat er meerdere symbolische interpretaties bestaan, verschillend per doelgroep of betrokkene. De Blob in Eindhoven wordt door bestuurders geduid als het symbool van de stad van kennis \& design, terwijl diverse burgers en journalisten het object definieerden als het bruuskeren van het historische industriële verleden van de stad. ${ }^{1}$ Voor de een kan een prestigeproject het symbool zijn van stedelijke vooruitgang, maar voor de ander van falend bestuur. Verheul (2012) spreekt over een 'narratieve nastrijd': ook na de totstandkoming projecteren betrokkenen en publiek hun betekenissen en percepties van succes en falen op een project. Dit impliceert ook dat 'in the eye of the beholder' de perceptie van succes of falen in de loop van de tijd kan veranderen (Bovens \&'t Hart, 1996).

Prestigeprojecten zijn regelmatig controversieel van aard. We zien soms beeldbepalende gebouwen die op papier (of scherm) betoveren, maar vroeg of laat hun keerzijde laten zien. Afhankelijk van de ontwikkelfase waarin zij verkeren, is een reeks van tegenslagen te onderkennen. Sommige projecten blijven steken in de ideeënfase, omdat de initiatiefnemer de organisatie en omgeving niet meekrijgt, zoals de landmark-plannen van de Haagse wethouder Norder voor een M-gebouw van Koolhaas op het plein voor Den Haag Centraal, of de zwevende pont boven de haven van Scheveningen. ${ }^{2}$ Andere prestigeprojecten stranden in de voorbereidingsfase, zoals de Yantai-campus van de Rijksuniversiteit Groningen, of de marinekazerne in Vlissingen. Ze kunnen ook vastlopen in de uitvoeringsfase. Denk aan de Maastrichtse Calatrava Campus (alleen het fundament werd aangelegd), het half afgebouwde nieuwe Kasteel van Almere (thans een ruïne), het Schiekadeblok in de Rotterdamse spoorzone (mislukte gronddeal), of het Rotterdamse poppodium Waterfront (frauduleuze verbouwing en faillissement). ${ }^{3}$

Zelfs projecten die uiteindelijk wel tot stand komen, kunnen hun keerzijde hebben. Denk daarbij bijvoorbeeld aan de hoge prijs die een gemeenschap (of initiatiefnemer) moet betalen, zoals bij het door een woningcorporatie samen met een middelbare scholengemeenschap aangekochte en herontwikkelde cruiseschip SS Rotterdam (enorme kostenoverschrijding), of projecten waar de opbrengsten (output en outcomes) achterblijven, zie entertainmentboulevard Miracle Planet in Enschede, het Maankwartier in Heerlen, het Honkbalstadion in Hoofddorp (alle drie kennen leegstand), of de diverse Floriadeterreinen van de afgelopen decennia. ${ }^{4}$

1 Zie over de Blob de documentaire 'Betoog en Beton' (Spiegelfilm, 2016).

2 https://architectenweb.nl/nieuws/artikel.aspx?ID=23986 en https://architectenweb.nl/nieuws/ artikel.aspx?ID=33934

3 www.nrc.nl/nieuws/2017/04/17/wie-wist-wanneer-van-waterfront-8262624-a1554887

4 Het onderzoeksjournalistieke programma Pointer van KRO/NCRV wijdde een uitzending aan de tegenvallende resultaten van de Floriade in Almere en andere prestigeprojecten. 


\section{Grote kosten(overschrijdingen)}

Prestigeprojecten zijn vaak langdurig en kapitaalintensief. Vaak wordt sowieso niet gekozen voor het goedkoopste ontwerp. Een prestigeobject moet boven de middelmaat uitkomen. Denk bijvoorbeeld aan de Erasmusbrug. Het Rotterdamse stadsbestuur kon kiezen uit meerdere alternatieven. Het stadsbestuur wilde niet gaan voor het goedkopere alternatief, de zogenoemde 'utilitaire, civiele oeververbinding'; nee, de nieuwe brug moest een echt grote uitstraling hebben. In het raadsdebat over de keuze voor een brug werd zeer uitbundig en prozaïsch de voorkeur voor het duurste ontwerp uitgesproken en tegelijkertijd werd waarschuwend verwezen naar de stadsschouwburg aan het Schouwburgplein, dat recent was gerealiseerd, maar als veel te sober werd bevonden. Die teleurstelling wilde het stadsbestuur met de nieuwe stadsbrug niet nog een keer beleven en mede daarom werd het duurste en meest prestigieuze alternatief gekozen (Verheul, 2012). De beschikbare gemeentelijke middelen waren beperkt, dus moest Rotterdam naast steun van het Rijk, ook diep in de eigen buidel tasten.

Regelmatig worden prestigeprojecten nog duurder dan aanvankelijk begroot of voorgesteld. We kunnen daarvoor enkele oorzaken noemen (Altshuler \& Luberoff, 2003; Flyvbjerg, Bruzelius \& Rothengatter, 2003; Van Marrewijk, 2015). Om te beginnen zijn grote projecten een kwestie van de lange termijn, waarbij wisselende economische cycli zorgen voor prijsopdrijving, vertraging en daarmee stijgende kosten. Gedurende de rit nemen de kosten voor materiaal en personeel toe. Vanwege schaarste in de bouwsector worden bouwprojecten geregeld uitgesteld. Er zijn dan geen aannemers te vinden die het voor het begrote bedrag kunnen bouwen. Daarnaast zijn grote prestigieuze stadsprojecten doorgaans geen 'standaardproduct'. Zo bleken de organische vormen van Calatrava's ontwerpen moeilijker realiseerbaar, kreeg de Erasmusbrug te maken met wiebelende tuien en bleek de Markthal op een archeologische vindplaats te liggen. Ook bleken op diverse nieuwe trein- en metrostations IT-systemen voor beveiliging onvoldoende te werken, zoals bij de Hoekse Lijn naar Hoek van Holland, de Hogesnelheidslijn, of het nieuwe vliegveld in Berlijn. In al deze gevallen leidde dit tot grote budgetoverschrijdingen.

Bij prestigieuze stadsprojecten zijn gedurende het hele proces regelmatig veranderende politieke en maatschappelijke voorkeuren en bijgestelde eisen aan de orde. Gedurende het besluitvormingsproces willen verschillende betrokken politieke partijen, gebruikers- en belangengroepen dat hun voorkeuren worden toegevoegd aan het plan. Er wordt gevraagd om meer te investeren in gebruikscapaciteit, aparte ruimten voor specifieke doelgroepen, duurdere materialen, extra veiligheidsmaatregelen en andere kostenverhogende posten die worden verdedigd onder het motto 'laten we het maar in één keer goed doen'. Daarbij komen ook aanvullende proceskosten voor participatie, vooronderzoek, second opinions en juridische bijstand vanwege vertragingen, contractuele aanpassingen en rechtszaken. Daarnaast kennen grote projecten ook hun eigen complexe interne dynamiek, waaronder publiek-private samenwerking of ondergrondse risico's, 
waardoor financiële en temporele overschrijdingen vaak voorkomen (Van Marrewijk, 2015).

Bij prestigeprojecten spelen ook psychologische mechanismen een rol die tot kostenoverschrijding kunnen leiden. Er kan sprake zijn van onbewuste, maar vaak ook strategische kostenonderschatting door voorstanders (Flyvbjerg et al., 2003). De protagonisten zijn zo 'verliefd' op hun project, dat sprake is van 'optimism bias': 'het plan is zo mooi en belangrijk en we zijn zo toegewijd aan het project, dat het vast wel goed zal komen', zo luidt de opvatting. Tunnelvisie, een gebrek aan expertise en tegenspraak houden deze bias in stand. 'Strategische kostenonderschatting' betekent dat initiatiefnemers en hun adepten bewust de kosten lager voorstellen om het project erdoor te krijgen. Flyvbjerg et al laten op basis van interviews zien dat betrokken initiatiefnemers of voorstanders zelf ook toegaven dat zij de kosten laag voorstelden, omdat met een realistischer kostenplaatje het project nooit door de besluitvorming heen zou komen.

Ook treedt wel het fenomeen van 'verstrikking' op, zoals onder meer te zien bij de ontwikkeling van de Stopera in Amsterdam of het stadhuis van Apeldoorn (Otten, 2000). Als eenmaal bepaalde beslissingen zijn genomen, kosten zijn gemaakt, overeenkomsten en andere afhankelijkheden zijn ontstaan, blijkt het heel lastig om goed overzicht te houden over de kosten en baten van een project. Over het nieuwe Stadshart van Almere zei architect Rem Koolhaas dat zij als architecten en supervisor bewust een complex geheel van afhankelijkheden creëerden, zodat partijen aan elkaar 'geketend' werden en slechts het 'doorgaan op de ingeslagen weg' als enige optie werd ervaren (Verheul, 2012).

Waarom stoppen bestuurders niet met een veel te duur prestigeproject? In de leiderschapspsychologie wordt gewezen op de 'escalatie van commitment', op het vasthouden aan de reeds ingezette koers, terwijl de kosten oplopen en tegenvallers zich ophopen (Staw, 1981). Hier speelt ook het verschijnsel 'groupthink' een rol: de tunnelvisie die ontstaat door een te eenzijdige groepsblik, mede als gevolg van een eenzijdige groepssamenstelling (Janis, 1972; 't Hart, 1994). Een andere psychologische oorzaak is 'interne of externe zelfrechtvaardiging'. Daarvan is sprake als bestuurders ondanks de tegenvallers toch vasthouden aan hun eigen eerdere ambities en argumenten ('want het project vond ik destijds nu eenmaal een goed initiatief'). Externe zelfrechtvaardiging vindt plaats als de omgeving op de (onzekere) leider druk uitoefent om door te gaan, of vanuit de perceptie dat de achterban consistentie (vasthouden aan de ingezette koers) waardeert. Stoppen of bijstellen wordt dan als falen of zwakte gezien (Staw, 1981). Er zijn bovendien niet veel bestuurders die de geschiedenis willen ingaan met het niet laten doorgaan of halverwege afbreken van een project.

\section{Tegenvallende opbrengsten?}

Naast kostenoverschrijding kunnen ook de opbrengsten van prestigeprojecten na voltooiing tegenvallen. Daarbij moeten we kijken naar de directe en de indirecte 
opbrengsten. Prestigieuze gebouwen als zodanig kunnen niet goed functioneren, zoals dat het geval is bij het beeldbepalende onderwijsgebouw in de omgeving van het station Leiden Lammenschans van Thomas Rau. De directe financiële opbrengsten van zulke stadsprojecten betreffen doorgaans de exploitatie van een gebouw. De exploitatie-opbrengsten bestaan uit bijvoorbeeld de verhuur, verkoop, lease- of erfpachtinkomsten, meestal gedekt door een exploitant en de kaartverkoop, uitgaven aan restauratieve voorzieningen, onderverhuur van zalen, en subsidies voor bijvoorbeeld sport, kunst en cultuur. Tegenvallende opbrengsten kunnen in al deze categorieën ontstaan en hebben soms een onderling versterkend effect. Het half afgebouwde Kasteel van Almere, bedoeld als lokaal uitgaanscentrum, is thans een ruine en heeft niets opgeleverd. Noch grondopbrengsten, noch exploitatie-inkomsten.

Er zijn ook projecten die wel qua bouw zijn afgerond, maar (vrijwel) leeg staan. Berucht in dit verband zijn de stadions die zijn gebouwd voor het WK voetbal of de Olympische Spelen. In Athene zijn olympische stadions overwoekerd met onkruid en in Montreal en in Shanghai staan stadions die nauwelijks worden gebruikt. In Nederland kennen we de beruchte traditie van Floriade-evenementen, waarbij niet alleen de kosten enorm worden overschreden, maar ook de plannen voor het hergebruik van het vastgoed, of het aantrekken van nieuwe bedrijven en blijvende werkgelegenheid in de post-evenementfase tegenvalt. ${ }^{5}$ In Noord-Brabant hoopt men verspreid over de provincie zogenoemde Van GoghTorens te bouwen, met de intentie honderdduizenden toeristen te trekken, maar de inpassing in het landschap en de veronderstelde bezoekersstromen worden betwist. ${ }^{6}$ Gelukkig komt het in de reguliere bouw van maatschappelijk vastgoed niet vaak voor dat gebouwen volledig ongebruikt achterblijven, maar ook diverse stadstheaters, concertzalen en musea hebben te maken met tegenvallende kaartverkoop of dalende inkomsten vanwege teruglopende rijkssubsidies. Het gevolg is dat er regelmatig geld bij moet van de lokale overheid om faillissement, c.q. sluiting te voorkomen.

Het kenmerk van stadsprojecten is doorgaans dat ze niet uitsluitend zijn bedoeld om directe opbrengsten uit exploitatie te genereren, maar dat ze ook grotere uitstralingseffecten beogen op omliggende wijken en op de stad als geheel. Dit kunnen we als de indirecte opbrengsten zien. Hier ligt een essentiële legitimatie om hoge realisatiekosten te accepteren: een prestigieus stadsproject kan de aanjager zijn van de economische, sociale en culturele ontwikkeling van de stad. Op die manier kunnen dure investeringen worden gerechtvaardigd (Verheul, 2013). Maar ook dan is succes niet verzekerd. Nobele ambities worden gebruikt in de besluitvorming, maar de praktijk is weerbarstig.

In theorie dragen prestigieuze stadsprojecten bij aan de lokale werkgelegenheid, denk aan de bouwvakkers tijdens de bouwfase, en aan de lokale economie, denk

5 www.ad.nl/binnenland/floriade-forse-tegenvaller-voor-toeristenbranche a88b85bd/

6 www.bd.nl/brabant/hoe-hoog-mag-vincent-van-gogh-in-brabant-van-de-torenblazen a4248bfa/?referrer=https\%3A\%2F\%2Fwww.google.com\%2F 
aan de horeca-inkomsten tijdens de gebruiksfase. Toch moeten we ons bewust zijn van enkele 'dempende effecten', waardoor de opbrengsten voor de stad behoorlijk kunnen tegenvallen (Van Duijn \& Verheul, 2015). Zo is er economisch gezien het 'vervangingseffect': uitgaven aan sportwedstrijden of culturele evenementen vervangen uitgaven aan andere soortgelijke doelen; stadsbewoners kunnen een euro maar één keer uitgeven, dus niet altijd groeit de 'economische taart'. Daarnaast is er het 'verdringingseffect': door de drukte van een cultureel of sportevenement blijven stadsbezoekers weg. Voorts bestaat er het 'lekkage-effect': als vanwege de vrijemarktwerking en aanbestedingsregels de bouw van een groot project door buitenlandse bedrijven wordt gedaan, heeft de eigen stad er weinig aan wat werkgelegenheid betreft.

\section{Positieve uitstralingseffecten voor de omgeving?}

Ook voor omliggende wijken kunnen de veronderstelde spin-offs afwezig of gering zijn. De ontwikkeling van het Eye Museum in Amsterdam-Overhoeks beoogde een impuls te geven aan de werkgelegenheid voor de omliggende wijken in Amsterdam-Noord, maar uit onderzoek bleek dat bij de exploitatie geen werknemers uit de omliggende wijken betrokken zijn (Romkes, 2016). Een arbeidsmarkt functioneert immers vooral stadsregionaal en beperkt zich niet tot de omliggende wijken. De werkgelegenheidslegitimatie is vooral in Angelsaksische landen groot. In het VK en in de VS worden voortdurend projecten gelegitimeerd door te wijzen op het grote aantal banen die deze opleveren. Hoewel de meetmethoden ter discussie staan (hoe hard en nauwkeurig is het veronderstelde causale verband tussen project en banen in de omgeving?), wordt vooral ook het type banen bediscussieerd: zijn het niet vooral de slecht betaalde banen in de horeca die door de grootse stadsprojecten worden gecreëerd?

Prestigieuze stadsprojecten genereren ook indirecte opbrengsten in sociaal-culturele zin. Denk aan beeldbepalende publieke gebouwen die zorgen voor toegenomen trots onder de lokale bevolking. De vraag is echter voor wie de prestigieuze stadsprojecten eigenlijk zijn bedoeld, wie er gebruik van maken en wie er trots op zijn (Majoor, 2009; Doucet, 2010). De programmering is daarbij doorslaggevender dan de architectuur. Richten de activiteiten zich op een brede of beperkte doelgroep? Hoe betaalbaar zijn ze? In het Amsterdamse Eye Filmmuseum gaven bewoners uit de omliggende volkswijken aan dat ze nooit in dat gebouw komen, omdat ze daar alleen maar 'stomme films draaien uit de jaren twintig' en de koffie op het terras er veel te duur is (Romkes, 2016). Ook de publieke ruimte rondom een prestigeproject is van belang. Dikwijls is de openbare ruimte rondom een museum, theater, concertzaal of ander object erg kaal, steriel en niet erg uitnodigend voor verblijfsactiviteiten (Verheul, 2017). Stadsprojecten vragen om 'verankering', om een goede fysieke verbondenheid met de omgeving en om een sociaalculturele strategie om bewoners erbij te betrekken (Verheul, 2016). Als dat niet gebeurt, dan is een prestigieus bouwwerk niet meer dan een 'cathedral in the dessert' (Ashworth, 2011): het project heeft dan een 'autistische relatie' met de omgeving. 
Uiteindelijk zullen kosten en baten van prestigeprojecten tegen elkaar moeten worden afgewogen. Tijd kan een belangrijke rol spelen in de waardering, belevenis en betekenis van prestigeprojecten. Het Calatrava-project in Valencia werd eerst bejubeld en later beschimpt vanwege de hoge afbetalings- en onderhoudskosten. De Øresund-brug tussen Malmö en Kopenhagen werd eerst gezien als een symbool van Europese eenwording en economische voorspoed, maar later als een culturele en economische barrière (Van Marrewijk, 2017). Door ook naar indirecte opbrengsten te kijken hoeft een kostenoverschrijding niet altijd een probleem te zijn. Het Sydney Opera House, de Nederlandse Deltawerken, de Amsterdamse Noordzuidlijn, de ondertunneling van het spoor in Delft, ze kennen allemaal kostenoverschrijdingen of een gebrek aan directe inkomsten, toch zijn er maar weinig mensen die aan de hoge economische of sociale opbrengsten van deze projecten twijfelen. Soms kunnen op het eerste gezicht geslaagde projecten later tegenvallen en soms kunnen projectfiasco's alsnog meevallen. Het woningbouwproject de Blauwe Stad in Oost-Groningen wist zich na jarenlange mislukking en onverkochte kavels te richten op de bewoners uit de eigen regio, in plaats van de aanvankelijke focus op het aantrekken van kapitaalkrachtige bewoners vanuit andere landsdelen. Zodoende is, ondanks de grote afboekingen op de grondexploitatie, de Blauwe Stad alsnog op weg naar een (bescheiden) succes. Uiteindelijk verwacht men met een huidig bouwaantal van dertig woningen per jaar het project in 2051 af te kunnen ronden.

Levert een ruimtelijke investering als we maar lang genoeg wachten uiteindelijk wel wat op? Indien we daar van uit (willen) gaan, betekent dit dat we het vertraagde succes van dure projectvoorstellen en iedere grote kostenoverschrijding $a$ priori voor lief moeten nemen? Dat voert te ver. Veel van de opbrengsten worden niet gehaald, ze vragen om een uitgewerkte onderbouwing en strategie. Anders verworden ze tot een zogenoemde white elephant: een object waarvan nog steeds op inkomsten wordt gehoopt die de gemaakte hoge kosten kunnen compenseren (Rius-Ulldemolins, Hernàndez, Martí \& Torres, 2016).

\section{Manische symptomen en gedragsmechanismen}

$\mathrm{Nu}$ we de implicaties van prestigeprojecten hebben behandeld, gaan we nader in op de symptomen en achterliggende mechanismen van bestuurlijke manie. Niet alle tegenvallers, zoals kostenoverschrijdingen of teleurstellende opbrengsten van prestigeprojecten, zijn altijd te wijten aan bestuurlijke manie of mismanagement, ieder project kan immers worden overvallen door externe factoren. Maar toch kunnen we in de verschillende ontwikkelfasen van controversiële prestigeprojecten symptomen en mechanismen van bestuurlijke manie tegenkomen.

In de besluitvormingsfase zien we publieke leiders die te zeer verliefd zijn op hun eigen project en die het verkopen met mooie woorden, maar holle frases, in plaats van met degelijke kosten-batenanalyses of burgerbetrokkenheid in hun planvorming (zie Mouter \& Pelzer, 2021: in dit nummer). We zien ook bestuurders en overheidsmanagers die overmoedig zijn en onverantwoorde risico's nemen. De 
Rotterdamse Rekenkamer concludeerde op basis van een meta-analyse van tien jaar rekenkameronderzoeken dat de gemeente Rotterdam aan 'bestuurlijke overmoed' lijdt, aldus directeur Paul Hofstra (Bokhorst \& Verheul, 2021: in dit nummer). Onder meer bij het Schiekadeblok en het Warmtenet raakte de gemeente verstrikt in omvangrijke projecten waarbij planningsoptimisme heerste en te grote risico's werden genomen. ${ }^{7}$ We zien ook dat bestuurders bij semipublieke of private projecten met een overheidsaandeel (zoals een voetbalstadion) niet open en eerlijk durven te zijn over de financiële risico's uit angst investeerders af te schrikken of oppositie in de gemeenteraad te voeden.

Manische mechanismen zien we niet alleen in de besluitvormingsfase rond grote projecten, maar evengoed in het management van de uitvoering. Als de uitvoeringsorganisatie niet de capaciteit en professionaliteit bezit om met lastige tegenvallers of malafide partners om te gaan, dan is een ambitieus project gedoemd te mislukken (hoe mooi of stevig onderbouwd de plannen en ambities ook zijn). Dit zagen we bijvoorbeeld bij Poppodium Waterfront, waar medewerkers van de gemeentelijke vastgoedorganisatie druk ervoeren vanuit het bestuur en management om tot uitvoering en exploitatie te komen, maar ondertussen geen weerstand wisten te bieden tegen frauduleuze samenwerkingspartners (zie Verheul \& Schönau, 2021: in dit nummer). Manie is volgens sommigen inherent aan commercieel vastgoed en daar worden publieke bestuurders in meegesleept, zo stelt onderzoeksjournalist en auteur van 'De Vastgoedfraude' Vasco van der Boon (Bokhorst \& Verheul, 2021: in dit nummer). Soms gebeurt dit ten faveure van eigen gewin, maar soms ook doordat lokale bestuurders door hun kortetermijnbetrokkenheid en ongelijke positie geen tegenpartij zijn voor vernuftige vastgoedtypes.

Verscheidene gevallen, zoals het Poppodium Waterfront, het Kasteel van Almere of de verschillende stadionprojecten, evenals voorbeelden uit de woningcorporatiesector, laten mechanismen zien die we vaker tegenkomen in de onderzoeksrapporten over mislukte of teleurstellende projecten: een 'can do'-mentaliteit wordt gecombineerd met te weinig aandacht voor de daadwerkelijke bijdrage aan het publieke belang en voor zorgvuldige uitvoeringsprocessen. De kritische geluiden of financiële tegenvallers zijn gedurende de planvorming en uitvoering soms duidelijk zichtbaar. Publieke leiders raken in hun eigen projecten verstrikt, of er treedt een 'escalatie van commitment' op voor een reeds ingezette koers, vanuit de perceptie dat de aanvankelijke ambities goed waren, of vanuit de hoop dat positieve resultaten zich (ooit) zullen manifesteren, dan wel vanuit de veronderstelling dat consistentie (volharding) wordt gewaardeerd door de achterban (Staw, 1981).

Bij tegenvallers of misstanden is er vaak geen ruimte voor kritiek, ook niet binnen de organisatie zelf wanneer de cultuur daar geen ruimte voor biedt. In de schaduw van de betovering, de aandacht en het blinde geloof (de manie) in het realisatievermogen van grote, prestigieuze projecten, bevindt zich een wereld waar minder 
Tabel 1 Manische symptomen en gedragsmechanismen zichtbaar bij prestigeprojecten

\begin{tabular}{|c|c|c|}
\hline Projectfase & $\begin{array}{l}\text { Manische symptomen en gedragsmecha- } \\
\text { nismen }\end{array}$ & $\begin{array}{l}\text { Zichtbaar bij (voorbeel- } \\
\text { den uit NL) }\end{array}$ \\
\hline $\begin{array}{l}\text { Idee- en ontwerp- } \\
\text { fase }\end{array}$ & $\begin{array}{ll}- & \text { Dromen willen verkopen } \\
- & \text { Visuele verleiding van artist impressions } \\
- & \text { (Persoonlijke) 'legacy building' } \\
- & \text { Herhaling van holle frases zonder stevige } \\
& \text { onderbouwing }\end{array}$ & $\begin{array}{l}\text { M-gebouw van Koolhaas op } \\
\text { het plein voor Den Haag } \\
\text { Centraal; zwevende pont } \\
\text { boven de Scheveningse } \\
\text { haven; Brabantse Van } \\
\text { Gogh-Torens }\end{array}$ \\
\hline $\begin{array}{l}\text { Plan- en besluitvor- } \\
\text { mingsfase }\end{array}$ & $\begin{array}{ll}\text { - } & \text { Opportunistische beïnvloeding van kos- } \\
\text { - } & \text { ten-batenanalyses } \\
\text { Strategische kostenonderschatting/ } \\
\text { - } & \text { Opbrengstenoverschatting } \\
- & \text { Verstrikking overmoed } \\
- & \text { Venodigde partijen }\end{array}$ & $\begin{array}{l}\text { Yantai-campus RUG; ROC } \\
\text { Leiden Lammenschans; } \\
\text { Maastrichtse Calatrava } \\
\text { Campus; Warmtenet } \\
\text { Rotterdam; diverse sta- } \\
\text { dionprojecten }\end{array}$ \\
\hline Implementatiefase & $\begin{array}{ll}- & \text { Rijdende trein niet stoppen } \\
- & \text { Escalatie van commitment } \\
- & \text { Alles zelf doen zonder inschakeling } \\
& \text { externe deskundigheid } \\
- & \text { Vertrouwen op te kleine/niet-weerbare } \\
& \text { uitvoeringsorganisatie } \\
- & \text { Geen openheid over tegenvallers } \\
- & \text { Uitgaven in allerlei potjes onderbrengen } \\
& \text { wat financieel (extern) toezicht compli- } \\
& \text { ceert } \\
- & \text { Geen ruimte/cultuur voor interne kritiek }\end{array}$ & $\begin{array}{l}\text { Het Kasteel van Almere; } \\
\text { Chassé Theater Breda; } \\
\text { Muziekgebouw Eindhoven; } \\
\text { Rotterdams Schiekadeblok; } \\
\text { Stopera Amsterdam; Stad- } \\
\text { huis Apeldoorn; Poppo- } \\
\text { dium Waterfront; SS } \\
\text { Rotterdam; De Tirrel Win- } \\
\text { sum; Floriade Almere }\end{array}$ \\
\hline $\begin{array}{l}\text { Gebruiks- en evalu- } \\
\text { atiefase }\end{array}$ & $\begin{array}{ll}\text { - } & \text { Tegenvallende exploitatie (witte olifanten, } \\
\text { 'de eeuwige belofte') } \\
-\quad \text { Autistische relatie met omgeving } \\
-\quad \text { Re-framing van winst en verlies } \\
-\quad \text { Zelfrechtvaardiging na foutief (of fraudu- } \\
\text { leus) gedrag }\end{array}$ & $\begin{array}{l}\text { Heerlens Maankwartier; } \\
\text { Floriade(terreinen); Miracle } \\
\text { Planet Enschede; Eye } \\
\text { Museum Amsterdam; Blob } \\
\text { Eindhoven; Blauwe Stad, } \\
\text { Oost-Groningen }\end{array}$ \\
\hline
\end{tabular}

aandacht voor is: de dagelijkse praktijk van bureaucratische ambachtelijkheden, zorgvuldigheid en controle. Diverse corporatiebestuurders bij onder meer Vestia, Rochdale, Woonbron en Servatius hebben in de 'herfst' van hun leiderschapsperiode manisch gedrag en bestuurlijk of moreel verval getoond (zie Bokhorst, 2021: in dit nummer). Bestuurders gaven de ja-knikkers in hun managementteam privileges (bijvoorbeeld: 'voortaan gratis lunch in de kantine'), en intimideerden de nee-knikkers (bijvoorbeeld: om 6 uur in de ochtend in het donker op kantoor ontbieden). Manisch gedrag van publieke leiders brengt veel schade toe aan de organisatie, medewerkers en projecten.

We hebben de symptomen en mechanismen van bestuurlijke manie in tabel 1 samengebracht. 


\section{Bestuurlijke manie nader geduid}

Bestuurlijk gedrag heeft onzes inziens manische kenmerken als het de trekkers, de uitvoerende organisaties en de omgeving van projecten begeestert, maar er tegelijkertijd weinig oog is voor de risico's van deze projecten. Bestuurlijk gedrag is manisch als er een groot geloof in de opstartfase van het project is, maar onvoldoende aandacht voor de uitwerking en de uitvoering, of wanneer een project wordt neergelegd bij een organisatie die bijvoorbeeld niet weerbaar is tegen frauduleuze praktijken. Bestuurlijk handelen is manisch als kritische tegengeluiden niet worden gehoord of worden genegeerd. Bestuurlijk handelen is manisch als strategische kostenonderschatting en opbrengstenoverschatting de financiële besluitvorming bepalen, als bestuurlijk wensdenken onvoldoende is onderbouwd en tot 'luchtkastelen' of tot 'kathedralen in de woestijn' leidt. Bestuurders vertonen manisch gedrag als zij hun foutief of zelfs frauduleus gedrag rechtvaardigen door te stellen dat de stad er zonder hun aanwezigheid en opereren slechter vanaf was geweest.

In handboeken psychologie lezen we dat 'manisch' wordt omschreven als 'overmatige toestand van intense euforie, geluk, optimisme'. En in extreme vorm als: 'een volledig gebrek aan inhibitie bij relaties, geldsmijterij, (...) een onbedwingbaar goed humeur dat kan veranderen in woede en een bedriegende houding, (...) een onverantwoord optimisme, vrijgevigheid, absurde bedrijfsinvesteringen' (Roediger, Capaldi, Paris, Polivy \& Herman, 1996). Omdat deze manische trekken meestal opgevolgd worden door depressieve stemmingsverandering en gedragingen, wordt in de psychologie de manie als een symptoom van een bipolaire stoornis beschouwd. De sociale psychologie vormt wat ons betreft een onmisbare aanvulling op het multidisciplinaire arsenaal aan perspectieven om de werking van het openbaar bestuur te analyseren en te begrijpen. Want niet slechts de juridische of organisatorische inrichting van het openbaar bestuur, of de economische principes van verdeling van schaarse middelen bepalen het verloop en de uitkomst van beleidsprocessen, de sociaalpsychologische kenmerken van bestuur en leiderschap zijn minstens zo belangrijk.

Bestuurlijke manie komt niet alleen bij prestigieuze stadsprojecten voor. Ook bij andere prestigeprojecten in het openbaar bestuur zien we kenmerken daarvan. ${ }^{8}$ Of het nu gaat om een hervorming van de politieorganisatie, de invoering van grootschalige IT-projecten, de decentralisatie van de jeugdzorg, de omgang van de toeslagenfraude bij de Belastingdienst, onderzoeksevaluaties tonen steevast aan dat bestuurders geregeld gevoelig zijn voor wensdenken en voor dromen die te ver af staan van de weerbarstige werkelijkheid. Daarbij zijn die bestuurders geneigd jaknikkers om zich heen te verzamelen en projecten door te zetten, ook als meerdere seinen op rood staan (Bordewijk \& De Vries, 2009). Omdat stadsprojecten goed zichtbaar zijn, hebben we ons primair op deze typen prestigeprojecten gericht, maar onze inzichten zijn breder toepasbaar. Het bestuurlijk gedrag 
bij prestigeprojecten geeft inzicht in de psychologie van mensen in machtsposities. Het analyseren daarvan bouwt voort op en voegt kennis toe aan de gedragsbestuurskunde: het deel van de bestuurskunde dat de gedragswetenschappen verbindt met de studie van de werking van het openbaar bestuur (Tummers et al., 2016).

\section{Slot: op zoek naar beteugeling van manie}

Waarachtige bestuurders kunnen het onmogelijke mogelijk maken. De vraag is echter welke prijs de gemeenschap bereid is om te betalen teneinde de verbeelding aan de macht te laten, en welk bestuurlijk kader nodig is om prestigeprojecten te laten slagen. Wat maakt dat een prestigeproject dat als een droom begint, als een nachtmerrie eindigt? Welk bestuurlijk kader helpt te voorkomen dat projecten die tot de verbeelding spreken, vroeg of laat een deprimerend resultaat opleveren?

Onze analyse biedt aanknopingspunten voor beteugeling van het fenomeen bestuurlijke manie. Besluitvorming en management in divers samengestelde, multidisciplinaire teams zijn een belangrijke voorwaarde om eenzijdigheden te voorkomen en gebalanceerd met sturingsdilemma's om te gaan (Verheul, Daamen, Heurkens, Hobma \& Van Zoest, 2019). Participatieve waarde-evaluatie en research by (co-)design kunnen hulpmiddelen zijn om burgers meer te betrekken bij het maken van afwegingen en invullingen, bij voorkeur niet op een enkel moment, maar gedurende incrementele planontwikkeling (zie Mouter \& Pelzer, 2021: in dit nummer). Ook voldoende intern en extern toezicht is van groot belang: denk daarbij aan democratische controle vanuit de gemeenteraad en second opinions en contract-expertises op basis van (wetenschappelijk) opdrachtonderzoek, evenals onafhankelijke rekenkamers en een vitale (onderzoeks)journalistiek (Bokhorst \& Verheul, 2021: in dit nummer).

In alle projectfases is het hoe dan ook verstandig om te zorgen dat partijen en individuen vrijuit hun kritische vragen en ideeën ter verbetering van plannen en projecten kunnen uiten. Bij de bevraging kan door medewerkers, politici, journalisten en onderzoekers de tabel met symptomen en mechanismen van dit artikel als hulpmiddel dienen. Maar het gesprek daarover binnen de organisatie vraagt om ruimte die daarvoor moet bestaan, of moet worden gecreëerd als die er niet is (zie Verheul \& Schönau, 2021: in dit nummer). En dat is niet altijd gemakkelijk te realiseren.

Het doorbreken van een gesloten organisatie- en overlegcultuur en het intervenieren in (ongelukkige) sociale configuraties is een van de lastigste opgaven die er is. Soms zullen daarbij inhoudelijke interventies helpen, denk aan een ander type beleid of nieuwe projectvoorstellen, en soms kunnen sociale interventies behulpzaam zijn, zoals een andere samenstelling van teams of samenwerkingspartners (Termeer, 2006). In uiterste gevallen van misstanden zijn klokkenluidersvoorzieningen van belang, zodat oplettende en bezorgde medewerkers die intern geen 
gehoor krijgen, alsnog een alarmerende functie kunnen vervullen en daarin worden beschermd (Bovens, 1990).

De vraag blijft natuurlijk vooral hoe we mislukte of teleurstellende prestigeprojecten als gevolg van bestuurlijke manie kunnen voorkomen. De genoemde symptomen en gedragsmechanismen komen doorgaans in meervoud en in onderlinge samenhang voor, dus dat vergoot de kans om het afglijden richting projectfiasco's op te merken. De studie naar bestuurlijke manie is een hulpmiddel om uit de hand lopende prestigeprojecten te kunnen beteugelen.

\section{Literatuur}

Altshuler, A., \& Luberoff, D. (2003). Megaprojects: The changing politics of urban public investment. Washington, DC: Brookings.

Ashworth, G. (2011). The instruments of place branding: How is it done? European Spatial Research and Policy, 16(1).

Boon, V. van der, \& Marel, G. van den. (2009). De vastgoedfraude. Amsterdam: Nieuw Amsterdam.

Bordewijk, P., \& Vries, J. de. (2009). Rijdende treinen en gepasseerde stations. Amsterdam: Van Gennep.

Bovens, M. (1990). Verantwoordelijkheid en organisatie. Zwolle: Tjeenk Willink.

Bovens, M.A.P., \& Hart, P. 't. (1996). Understanding policy fiascoes. New Brunswick: Transaction Publishers.

Doucet, B.M. (2010). Rich cities with poor people: Waterfront regeneration in the Netherlands and Scotland. Utrecht: KNAG.

Duijn, M. van, \& Verheul, W.J. (2015). Stadions als aanjager voor stedelijke gebiedsontwikkeling? Bestuurskunde, 24(4), 70-81.

Flyvbjerg, B. (2014). What you should know about megaprojects and why: An overview. Project Management Journal, 45(2), 6-19.

Flyvbjerg, B., Bruzelius, N., \& Rothengatter, W. (2003). Megaprojects and risk: An anatomy of ambition. Cambridge: Cambridge University Press.

Hall, P. (1980). Great planning disasters. Oakland: University of California Press.

Hart, P. 't. (1994). Groupthink in government: A study of small groups and policy failure. Baltimore: John Hopkins University Press.

Hospers, G.J., Verheul, W.J., \& Boekema, F. (red.). (2011). Citymarketing voorbij de hype: Ontwikkelingen, analyse en strategie. Den Haag: Boom Lemma.

Janis, I.L. (1972). Victims of groupthink: A psychological study of foreign-policy decisions and fiascoes. Houghton: Mifflin.

Klop, K. (1999). Verbeelding van de macht: Ethiek en esthetiek in architectuur, ornamentiek en kunst in overheidsgebouwen. Nijmegen: Valkhof Pers.

Majoor, S. (2009). The disconnectivity of new urbanity in Zuidas Amsterdam, Orestad Copenhagen, and Forum Barcelona. European Planning Studies, 16(9).

Marrewijk, A.H. van. (2015). Inside megaprojects: Understanding cultural practices in project management. In S.R. Clegg (Ed.), Advances in organization studies (pp. 13-32) Copenhagen: Copenhagen Business School Press.

Marrewijk, A.H. van. (2017). The multivocality of symbols: A longitudinal study of the symbolic dimensions of the high-speed train megaproject (1995-2015). Project Management Journal, 48(6), 1-13. 
Nelissen, N. (2003). Strijd om architectuur in Europa. Maastricht/Nijmegen: NN.

Otten, M. (2000). Verstrikt in grote projecten: Hoe de stadhuizen in Amsterdam en Apeldoorn tot stand kwamen. Den Haag: VNG.

Plaza, B., Galvez-Galvez, C., \& Gonzalez-Flores, A. (2011). Testing the employment impact of the Guggenheim Museum Bilbao via TSA. Tourism Economics, 17(1), 223-229.

Rius-Ulldemolins, J., Hernàndez I., Martí, G.M., \& Torres, F. (2016). Urban development and cultural policy 'white elephants': Barcelona and Valencia. European Planning Studies, 24(1), 61-75.

Roediger, H., Capaldi, E., Paris, S., Polivy, J., \& Herman, C. (1996). Psychologie: Een inleiding. Heerlen: Open Universiteit.

Romkes, D. (2016). Achter de façades van flagships. Delft: TU Delft.

Staw, R. (1981). The escalation of commitment in a course of action. The Academy of Management Review, 6(4), 577-587.

Sudjic, D. (2005). The edifice complex: The architecture of power. London: Penguin.

Termeer, K. (2006). Vitale verschillen: Over publiek leiderschap en maatschappelijke innovatie. Wageningen: WUR.

Tummers, L., Olsen, A.L., Jilke, S., \& Grimmelikhuijsen, S.G. (2016). Introduction to the virtual issue on behavioral public administration. Journal of Public Administration Research and Theory, (3), 1-3.

Verheul, W.J. (2012). Stedelijke iconen: Het ontstaan van beeldbepalende projecten tussen betoog en beton. Den Haag: Boom Lemma.

Verheul, W.J. (2013). Op zoek naar de heilige graal van katalysatorprojecten in stadsontwikkeling. Real Estate Research Quarterly, 12(4).

Verheul, W.J. (2016). Embedded developments: The connection between buildings and a place. In D. Broekhuizen (Ed.), Maison d'Artiste: An unfinished icon by the style (pp. 99-106). Rotterdam: Nai Publishers.

Verheul, W.J. (2017). Placemaking and the discourse of the public space. In J. Laven et al. (Eds.), The city at eyelevel in the Netherlands (pp. 232-243). Wageningen: Blauwdruk.

Verheul, W.J., Daamen, T., Heurkens, E., Hobma, F., \& Zoest, S. van. (2019). Leren van stedelijke transformaties: Over sturingsdilemma's en veerkracht in binnenstedelijke gebiedstransformaties. Den Haag: Platform31. 